УДК 378:78

DOI: 10.37026/2520-6427-2019-100-4-167-170
ОЛЬГа ГНЕПА,

кандидат педагогічних наук, викладач ВКНЗ «Володимир-Волинський педагогічний коледж імені А. Ю. Кримського»

\title{
МУЗИКОТЕРАПІЯ В ОСВІТНЬОМУ ПРОЦЕСІ ПЕДАГОГІЧНОГО КОЛЕДЖУ
}

У статті проаналізовано потенціал музикотерапії та розглянуто ї̈ лікувально-педагогічні властивості. Здійснено короткий історичний огляд здоров'язбережувального впливу музики. Висвітлено можливість застосування музикотерапї в освітньому прочесі закладів вищої освіти загалом та педагогічного коледжу зокрема.

Ключові слова: музикотерапія, майбутні вчителі, заклади вищої освіти, лікувальні властивості, музика.

В статье проанализирован потенцииал музыкотерапии и рассмотрены ее лечебно-педагогические возможности. Осуществлен краткий исторический обзор здоровьесберегающего влияния музыки. Освещена возможность применения музыкотерапии в образовательном процессе высших учебных заведений в иелом и педагогического колледжа в частности.

Ключевые слова: музыкотерапия, будущие учителя, высшие учебные заведения, лечебные возможности, музыка.

The article is devoted to the potential of music therapy and its therapeutic and pedagogical properties. A brief historical overview is performed according to health-saving influence of music. The importance of music's active use in hospitals, rehabilitation centers, kindergartens, schools, industry and agriculture is emphasized. The aspects of music therapy's using in educational process of higher educational institutions in general and pedagogical college in particular are elucidated in the article: keeping of health, improving the performance of students, activation of their interest to learning, increasing of activity and emotional stability, solving the problems of interpersonal communication.

Some experience of music therapy's using in medicine, psychiatry and pedagogics is gained in recent years in Ukraine. Music therapy is academic discipline in some Ukrainian higher educational institutions. Scientific and practical conferences, educational and methodical seminars about music therapy take place in Zaporizhia, Kyiv, Lviv, Ivano-Frankivsk.

The author's perennial experience of teaching in colleges allowes to conclude that the students are not able to eliminate nervous tension and to stabilizate emotional state. Music helps them to tune emotionally in to work and influence positively on their overall learning success. The preparing of future elementary school teachers was organized with periods of musical rest. Undoubtedly sound is important extraordinary source of energy. The scientists have established a relationship between the frequency of music vibrations and human physiological processes. Phon music, used during writing tests in college, activates mental and creative activity, predetermines reducing the number of mistakes and improving the quality of knowledge. The combination of pedagogical methods and managed musical influence allows reviving the spiritual and physical health of the society under the conditions the least financial cost.

Key words: music therapy, future teachers, institutions of higher education, therapeutic properties, music.

Постановка проблеми. Ефективна побудова освітнього процесу в закладах вищої освіти вимагає врахування не лише фізичного, а й психологічного стану його учасників. Не викликає сумнівів, що інтенсифікація та оптимізація освіти, зростання обсягу навчальної інформації, що засвоюється студентами, пов'язані з великими витратами їх нервово-психічної енергії. Для сучасної молоді характерні перевантаження інтелектуальною діяльністю, загальна емоційна напруженість, швидка стомлюваність, новий формат спілкування (через інтернет, соціальні мережі), схильність до самотності, неконтрольована агресивність тощо. Ураховуючи те, що стрес $є$ причиною виникнення близько дев'яноста відсотків захворювань, пошуки вчених різних галузей спрямовані на подолання негативних психічних станів і зміцнення здоров'я людей. Саме тому сьогодні значна увага приділяється впровадженню здоров'язбережувальних технологій у роботу закладів освіти. Особливої актуальності ця теза набуває в умовах збільшення в Україні кількості дітей з особливими освітніми потребами. У зв'язку 3 цим постає питання про застосування музики як психотерапевтичного та психокорекційного засобу в освітньому процесі закладів вищої освіти.

Аналіз наукових досліджень та публікацій. Наукові праці сучасних дослідників, зокрема С. Бакай, C. Бойченко, I. Волженцевої, В. Драганчук, Н. Квітки, Л. Кузьмінської, Л. Литвинчук, Г. Локарєвої, 
I. Малашевської, В. Петрушина, Г. Побережної, О. Сороки, Н. Терентьєвої, А. Тітової, Н. Товтин, О. Федій, С. Шушарджана, К. Щедролосєвої, розкривають сутність музикотерапії, іiі властивості та можливість упровадження в освітнє середовище.

Метою статті $\epsilon$ обгрунтування потенціалу музикотерапії та з'ясування доцільності її застосування в освітньому процесі закладів вищої освіти загалом та педагогічного коледжу зокрема.

Виклад основного матеріалу. Поліфункціональні і багатоаспектні можливості музики здавна привертали увагу вчених, філософів, психологів, педагогів, лікарів. Наші предки інтуїтивно відчували в музиці велику оздоровчу силу, хоча й не вміли пояснити цілющий ефект рідної української пісні. Цей феномен, який отримав назву «музикотерапія», був науково обгрунтований уже в наш час. Виявилося, що цілковита тиша негативно впливає на психіку людини, оскільки не $є$ для неї звичним навколишнім тлом. Термін «музикотерапія» має греко-латинське походження й у перекладі означає «зцілення музикою» $[10$, с. 291]. На сьогодні усталеного формулювання музикотерапії не існує, тому тлумачення значною мірою різняться між собою в різноманітних напрямах, зокрема:

- у медичному музика використовується з метою покращення чи збереження здоров'я людини [10, с. 289];

- y nсихотерапевтичному - допомагає досягти кращої внутрішньої й міжособистісної інтеграції та якості життя [1, с. 14];

- у педагогічному вона сприяє формуванню гармонійної особистості.

Не всім відомо, що термін «терапія» в перекладі $з$ грецької означає «турбота, догляд». Це пояснює той факт, чому дана дефініція увійшла до поняттєвого апарату педагогіки. Значні можливості має використання музикотерапії в освіті: збереження здоров'я та підвищення працездатності студентів, активізація їх інтересу до навчання, посилення активності, емоційної стійкості, вирішення проблем міжособистісного спілкування [1, с. 16; 7, с. 11-12].

Усі дослідники спільні в тому, що музика здійснює величезний вплив на психічні та фізіологічні процеси людського організму, оптимізацію процесів життєдіяльності. Цікавими, на нашу думку, є наукові розвідки про використання музики на виробництві (вивчення впливу музики на продуктивність праці робітників, зменшення емоційного напруження під час розумової праці конструкторів), у медицині (застосування музики з лікувальною метою), спорті (вивчення впливу музики на ефективність діяльності спортсменів), у педагогіці (використовується як виховний, психотерапевтичний і психокорекційний засіб) [2].

У ході наукового пошуку з'ясовано, що лікувально-педагогічні властивості музикотерапії використовувалися здавна. Цілющий вплив музики на духовний і фізіологічний стан людини був відомий ще тисячоліття тому. Згадки про це знаходимо в папірусах, складених жрецями Давнього Єгипту, і Біблії - найдавнішій писемній пам'ятці людства. Лікарі Давньої Греції, Китаю, Індії широко використовували увесь спектр музичного мистецтва на практиці: зціляли від смутку, безсоння, нервових розладів, епілепсії та серцевого болю [9, с. 224].

У середньовічних університетах музика відігравала провідну роль в освітньому процесі. Із чотирьох складових квадривіуму (арифметика, геометрія, астрономія, музика) саме музика протягом усього періоду становлення університетської освіти відігравала ключову роль [8, с. 48].
У Російській імперії перші наукові праці, що досліджують механізм дії музики на людину, з'явилися наприкінці XIX - поч. XX ст. У 1913 році В. Бехтерєв переконливо довів перевагу слуху над зором, помітивши, що дитина, глуха від народження, розвивається гірше, ніж сліпа. У роботах В. Бехтерева, І. Догеля, I. Сеченова, I. Тарханова наведено дані про активний вплив музики на фізіологічні реакції організму (дихання, центральну нервову систему, кровообіг та газообмін). Впливаючи на психічний стан людини, музика спричиняє певні гормональні і біохімічні зміни в організмі, позитивно діє на інтенсивність обмінних процесів. Емоції, що виникають під час звучання музики, запобігають втомі, знімають стреси, стимулюють інтелектуальну діяльність, підвищують працездатність [1, с. $13 ; 5 ; 8$, с. 49; 11].

Звук взагалі $є$ неординарним джерелом енергії. Учені встановили взаємозв'язок між частотою звукових коливань музики та фізіологічних процесів людини. Важливе значення при прослуховуванні музики має наша власна інтуїція. Якщо мелодія, яка в інших викликає покращення настрою, у вас забирає сили, то краще ii не слухати, а знайти собі мелодію до душі. Гучність - важливий фактор, від якого залежить ступінь впливу музики. Голосна музика порушує ритм серцебиття, зумовлює появу блідості, роздратованості і може призвести до серйозних психічних розладів, викликає підсвідоме відчуття тривоги, знижує працездатність (на розумові вправи іде на двадцять відсотків більше часу). Помірна музика, навпаки, надає відчуття спокою, впевненості, допомагає сконцентрувати увагу, налаштовує на роботу $[9$, c. $224 ; 11]$.

Зростання популярності використання музичного впливу спричинило необхідність розробки академічної програми підготовки професійних музикотерапевтів. Як навчальна дисципліна музикотерапія вперше 3'явилася у 1918 році в Колумбійському університеті. У 1975 році в Лондоні було засновано Центр музичної терапії. Сфера застосування музикотерапії у Великобританії, Австрії, Німеччині, Франції, Японії, Новій Зеландії, країнах Південної Америки постійно розширюється. Загалом за кордоном більше ста університетів і коледжів пропонують курси, після закінчення яких студенти отримують ступінь бакалавра або магістра [5; 10, с. 295]. Лікувальні можливості музики покладені в основу діяльності Інститутів музичної терапії у п'ятнадцяти країнах, зокрема Англії, Франції, Німеччині, Австрії, США та ін. [11].

Упродовж останніх років в Україні накопичено певний досвід застосування музикотерапії в медицині, психіатрії та особливо в педагогіці, яка, на жаль, ще не до кінця усвідомила значення музики як одного 3 найбільш доступних та ефективних факторів формування особистості. Досить актуальною для української педагогічної школи є профілактика стресів і неврозів, нормалізація душевного стану людини за допомогою музики, естетизація та гармонізація освітнього процесу. Зауважимо, що поєднання педагогічних методів iз керованим музичним впливом дозволить відродити духовне й фізичне здоров'я суспільства за умов найменших фінансових затрат [9, с. 224; 11$]$.

Проходять апробацію певні форми й методи підготовки педагогів до використання музикотерапії у професійній діяльності. 
Так, у Полтавському державному педагогічному університеті імені В. Короленка майбутні соціальні педагоги, педагоги-дефектологи та вихователі закладів дошкільної освіти вивчають музикотерапію як окремий розділ спецкурсів «Психолого-педагогічна терапія» та «Естетотерапія». Змінено концепцію підготовки майбутніх педагогів-музикантів у Національній музичній академії України ім. П. Чайковського, Запорізькому національному університеті, Мукачівському державному університеті, Національному педагогічному університеті ім. М. Драгоманова, де музикотерапія вивчається як окрема навчальна дисципліна. Проводяться науково-практичні конференції та навчально-методичні семінари з музикотерапії в Запоріжжі, Києві, Львові та Івано-Франківську. Як лікувальний метод музикотерапію застосовують в Інституті нетрадиційної медицини, Центрі реабілітації ім. О. Богомольця та в приватних клініках.

Ліцензію на проведення музично-терапевтичних сеансів із дітьми першим в Україні отримав у 2003 році Стефан Недериця - диригент, письменник, викладач. Ним презентовано серію аудіодисків класичної музики зі звуками природи для розвитку уяви, пам'яті, мислення [10, с. 297].

Без перебільшення можна стверджувати, що нагальною потребою сьогодення є звернення до практичної музикотерапії й повного використання iii творчого потенціалу [4]. Особливо це стосується студентів закладів вищої освіти загалом і педагогічного коледжу зокрема. Адже професія вчителя початкових класів пов'язана $з$ високою моральною відповідальністю та щоденним нервовим напруженням. Студенти фактично не володіють способами усунення нервово-психічної напруги і стомлення. Надати істотну допомогу в таких випадках може ознайомлення майбутніх педагогів із музико-терапевтичними практиками ще під час навчання в коледжі чи університеті.

Спочатку варто озброїти майбутніх учителів теоретичними знаннями, зокрема про форми музикотерапії (активну і пасивну), які розрізняють залежно від активності слухачів, рівня їх участі в музичному процесі і поставлених завдань. Активна музикотерапія досягається через власну музичну діяльність педагога та учнів (студентів), через відтворення музичного художнього образу, фантазування слухачів після його сприйняття, спільну імпровізацію мелодії за допомогою людського голосу та музичних інструментів. Одним із варіантів може бути хорове виконання твору, що створить атмосферу довіри між учнями (студентами). Пасивна (рецептивна) музикотерапія передбачає процес пасивного сприйняття (прослуховування) творів музичного мистецтва і може широко використовуватися педагогами незалежно від наявності спеціальної музичної освіти. Тому саме рецептивні форми організації навчальної діяльності вчителя стають найбільш актуальними технологіями використання музикотерапії для сучасної освіти [11].

Власний багаторічний досвід викладання математики у Волинському коледжі культури і мистецтв імені І. Стравінського (ВДУКІМ) дозволив зробити висновок, що музика допомагає студентам емоційно налаштуватися на роботу і позитивно впливає на їх загальну успішність. Підтвердженням цього факту $є$ дані досліджень британських учених: математика активізує ті ж ділянки мозку, що й музика. Доведено, що діти, які займаються музикою, краще засвоюють математику, зокрема геометрію. Сканування мозку засвідчує: при вивченні теми «Дроби» в музикантів сильніше, ніж у людей без музичної підготовки активізується та частина мозку, яка задіяна в абстрактному мисленні. Це відбувається тому, що навчання музики пов'язане 3 розумінням, запам'ятовуванням, читанням нотних текстів, які складаються переважно iз символів. Навички, сформовані таким способом, полегшують засвоєння математичної символіки. Сучасні дослідження вказують на те, що будь-які дії, приклади, розповіді під музичний супровід залишаються у пам'яті набагато довше.

Упродовж освітньої діяльності у ВДУКІМ нами вивчалися можливості та перспективи застосування музикотерапії в освітньому процесі вищої школи. Зі зміною місця роботи на ВКНЗ «Володимир-Волинський педагогічний коледж імені А. Ю. Кримського» роботу над дослідженням проблеми музичного впливу на особистість було продовжено. Зокрема, проведено анкетування студентів коледжу спеціальності «Початкова освіта» щодо їх музичних вподобань та ролі музики в навчанні. Майбутні вчителі початкових класів визнали бадьору музику (72 \% опитаних) найбільш ефективною для стимулювання критичного мислення, генерування творчих ідей. За жанром більшість опитаних (59 \%) віддають перевагу поп-музиці. За результатами анкетування з'ясовано, що студенти позитивно ставляться до використання музики в навчальному процесі. Цільова група дослідження - першокурсники, значна частина яких під час адаптації до навчання в коледжі відчуває страх, невпевненість у власних силах, має занижену самооцінку. Усе це може негативно вплинути на успішність і призвести до втрати інтересу до навчання.

Підготовку майбутніх учителів початкових класів до викладання було побудовано в такий спосіб, щоб студенти мали можливість відчути сприятливий вплив музики на власний емоційний та фізичний стан. На заняттях нами було впроваджено хвилини музичного відпочинку. Музика допомагала студентам відновити душевний спокій, створювала необхідні умови для ефективного здобуття знань, сприяла збереженню їх здоров'я. Фонова музика, яка використовувалася під час написання самостійних і контрольних робіт, активізувала розумову діяльність і творчу активність, зумовлювала зменшення кількості помилок і підвищення якості знань.

Висновки. За кордоном музика активно використовується в лікарнях, реабілітаційних центрах, дитячих садках, школах, промисловості та сільському господарстві. При цьому в Україні музикотерапія лише починає входити до соціального простору після столітнього поширення у світі. Зокрема впродовж останнього десятиріччя викристалізувалася ідея використання музикотерапії в національній освіті та були зроблені перші кроки в цьому напрямі. Зважаючи на означене вище, нами встановлено, що музикотерапія $\epsilon$ не лише важливим ресурсом збереження та відновлення здоров'я людини, але й одним із важливих чинників формування особистості.

Перспективи подалыших наукових досліджень вбачаємо у вивченні проблеми попередження синдрому професійного вигорання педагогів засобами музикотерапії. 


\section{СПИСОК ВИКОРИСТАНОЇ ЛІТЕРАТУРИ}

1. Бакай С. Ю. Музикотерапія та вокалотерапія у сучасному педагогічному процесі / С. Ю. Бакай, О. А. Мкртічян // Науковий часопис НПУ імені М. П. Драгоманова. - 2011. - Вип. 14. - С. 13-16. (Серія 16 «Творча особистість учителя: проблеми теорії і практики»). URL: http://nbuv.gov.ua/ UJRN/Nchnpu_016_2011_14_5 (дата звернення: 15.08.2019).

2. Волженцева I. В. Оптимізація психічних станів студентів у навчальній діяльності засобами музичного впливу : автореф. дис. на здобуття наук. ступеня канд. псих. наук : 19.00.07 «Педагогічна і вікова психологія» / І. В. Волженцева. - Київ, 2006. - 20 с.

3. Драганчук В. М. Музика як фактор психокорегування: історичний, теоретичний і практичний аспекти : автореф. дис. на здобуття наук. ступеня канд. мистецтвознавства : 17.00.03 «Музичне мистецтво»/ В. М. Драганчук. - Київ, 2003. - 20 с.

4. Квітка Н. Методичний посібник із музикотерапії для дітей дошкільного віку зі складними порушеннями психофізичного розвитку / Н. Квітка. - К. : 2013. -82 c.

5. Кузьмінська Л. Зміст та цілі музикотерапії в соціально-педагогічній роботі 3 дітьми-інвалідами / Л. Кузьмінська // Освіта регіону. Політологія. Психологія. Комунікації: український науковий журнал. 2011. - № 4. URL: http://www.social-science.com.ua/ article/711 (дата звернення: 18.08.2019).

УДК 78.071:780.616.432(477)

DOI: 10.37026/2520-6427-2019-100-4-170-173
6. Литвинчук Л. М. Особливості корекційного впливу музикотерапії / Л. М. Литвинчук // Проблеми сучасної психології : збірник наукових праць Кам'янець-Подільського національного університету ім. І. Огієнка. - 2012. - Вип. 15. - С. 322-330.

7. Малашевська I. А. Теорія і практика навчання музики дітей дошкільного та молодшого шкільного віку з використанням музикотерапії : автореф. дис. на здобуття наук. ступеня д-ра пед. наук : 13.00.02 «Теорія та методика музичного навчання». - Київ, 2017. - 36 с.

8. Терентьєва Н. О. Терапевтичний вплив музики: історико-методичний аспект / Н. О. Терентьєва, М. В. Гладков // Педагогічні науки : збірник наукових праць Херсонського державного університету. 2017. - Вип. 79. - Т. 2. - С. 46-51.

9. Тітова А. В. Можливості застосування музикотерапії у вищій школі та її вплив на успішність майбутніх лікарів / А. В. Тітова // Вісник ВДНЗУ «Українська медична стоматологічна академія». - 2015. Вип. 2 (50). - Т. 15. - С. 224-227.

10. Товтин Н. І. Історико-теоретичні засади музикотерапії / Н. І. Товтин // Україна - Цивілізація. Том 6. Консолідація української держави, нації та церкви: зовнішні та внутрішні чинники. - Ужгород : Видавничий відділ КаУ, 2017. - С. 289-298.

11. Щедролосєва К. О. Музикотерапія та ії лікувально-педагогічні можливості / К. О. Щедролосєва. URL: www.ksdu.ks.ua/FileDownload.ashx (дата звернення: 20.08.2019).

Дата надходження до редакиіï: 21.08.2019 р.

Жанна ДАЮК,

кандидат педагогічних наук, доцент кафедри естрадної музики Інституту мистеитв

Рівненського держсавного гуманітарного університету

Анастасія МОСІЙЧУК, студентка магістратури кафедри естрадної музики Інституту мистеитв

Рівненського держсвного гуманітарного університету

\section{ДИТЯЧА ФОРТЕПІАННА МУЗИКА НА ТЕРЕНАХ УКРАЇНИ}

У статті висвітлено питання про зародження дитячої фортепіанної музики та ї̈ представників на теренах України. Представлено періодизацію та аналіз творчої спадщини окремих композиторів. 3'ясовано, якою саме музикою виховували та прищеплювали в дітей любов до народної культури. Систематизовано та узагальнено відомості щзодо створених збірок, окремих ииклів фортепіанних п'єс для дітей, написаних відомими українськими композиторами.

Ключові слова: дитяча фортепіанна музика, цикли, п'єси, фортепіанні збірки, украӥнські композитори.
В статье освешены вопросы о зарождении детской фортепианной музыки и ее представителей на территории Украины. Представлена периодизачия $u$ анализ творческого наследия отдельных композиторов. Выяснено, какой именно музыкой воспитьвали и прививали у детей любовь к народной культуре. Систематизированы и обобщены сведения о созданных сборниках, отдельных ичиклах фортепианных пьес для детей, написанных известными украинскими композиторами.

Ключевые слова: детская фортепианная музы-

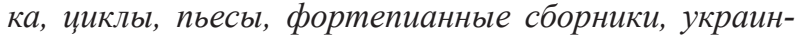
ские композиторы. 